\title{
Understory Species Richness during Restoration of Wet Tropical Forest in Costa Rica
}

\author{
A. Carl Leopold and Jackeline Salazar
}

\begin{abstract}
An effort to restore wet tropical forest in Costa Rica began in 1993 with plantings of native trees in abandoned pasture land. We compared understory plant species richness in three sites planted with a mix of native tree species with understory species in two monoculture plantations and in two secondary growth (unplanted) areas. Understory species in nearby primary forest remnants are also reported for comparison. We identified 356 understory species, ranging from 46 to 134 understory species per plot. Woody species were predominant (50-80\%), as were plant species relying on animals for seed dispersal (60-80\%). Our data indicate that substantial progress toward understory species richness can be obtained in the first decade of wet tropical forest restoration.
\end{abstract}

Keywords: Costa Rica, rainforest restoration, understory plant species

\section{Introduction}

Though more than 80 percent 1 of Earth's wet tropical forests have been destroyed (Panayatou and Ashton 1992, Lamb et al. 2005), very little is known about the possibility for the restoration of this forest type (Haggar et al. 1997). In 1992 the Tropical Forestry Initiative purchased approximately 145 ha of abandoned pasture land near Dominical, Costa Rica, with the goal of attempting tropical forest restoration. The land had been deforested, converted to grassland, and grazed by cattle for approximately 50 years (Boley 2005). In 1993 the Tropical Forestry Initiative began small-scale restoration with a mixed-species native tree planting (Leopold et al. 2001). A previous report described the progress of planted tree growth at the restoration site (Leopold 2005); this article reports on the number and diversity of understory species accumulated between 1993 and 2003.

Ecological Restoration Vol. 26, No. 1, 2008

ISSN 1522-4740 E-ISSN 1543-4079

@2008 by the Board of Regents of the

University of Wisconsin System.
A defining component of tropical forests is the richness of the plant community (Gentry 1990). In addition to the trees that form the foliar crown, understory plant species have a major influence on the functioning forest ecosystem (Brinson and Rheinhardt 1996). We compared the number and diversity of understory plant species found in 1) our plantings of mixed tree species; 2) nearby monoculture tree plantations; 3) secondary unplanted and unmanaged stands; and 4) nearby remnants of primary forest. We counted the number of understory species and recorded their form (arborescent, herbaceous, shrub, vine). We also noted their seed dispersal mechanisms (animal, wind, and ejection) to help us better understand how the plants moved into the plots.

\section{Measuring Incoming Species}

Our observations of tree growth at the restoration site reveal that the fastestgrowing trees are increasing in height at an average of $2.2 \mathrm{~m}$ per year, facilitated by the abundant rainfall $(4.1 \mathrm{~m}$ per year) and tropical temperatures (23 to $31^{\circ} \mathrm{C}$ ) (Peñuela 2001). After about five years the canopy was almost complete and the pasture grasses had died out, enabling understory species to spread rapidly into the replanted areas.

To assess the development of species richness, in 2003 we surveyed plants in 0.1-ha plots located in seven sites representing a range of treatments and ages. We compared plots in restoration areas (sites A, B, and C), monoculture plantations (sites D and $\mathrm{E}$ ), and unplanted secondary growth ( $F$ and $G$ ) (Figure 1). Plot $A$ is situated in a stand of approximately 8 ha of mixed species of native trees planted in 1993 (Figure 2), Plot B is in about a 4-ha planting started in 1995 , and Plot $\mathrm{C}$ is in about a 2-ha planting started in 1996. Table 1 lists the tree species planted in restoration plots A, $\mathrm{B}$, and C. Plots D and $\mathrm{E}$ are located in nearby monoculture plantations: plot $\mathrm{D}$ of the native pochote (Bombacopsis quinata), and plot $\mathrm{E}$ of the exotic teak (Tectona grandis). Plots F and G lie in unplanted, unmanaged secondary growth. Plots D through G are all about ten years old according to local landowners.

We compared the understory species of plots A through $\mathrm{G}$ with plots in two primary forest remnants ( $\mathrm{H}$ and $\mathrm{I})$. 


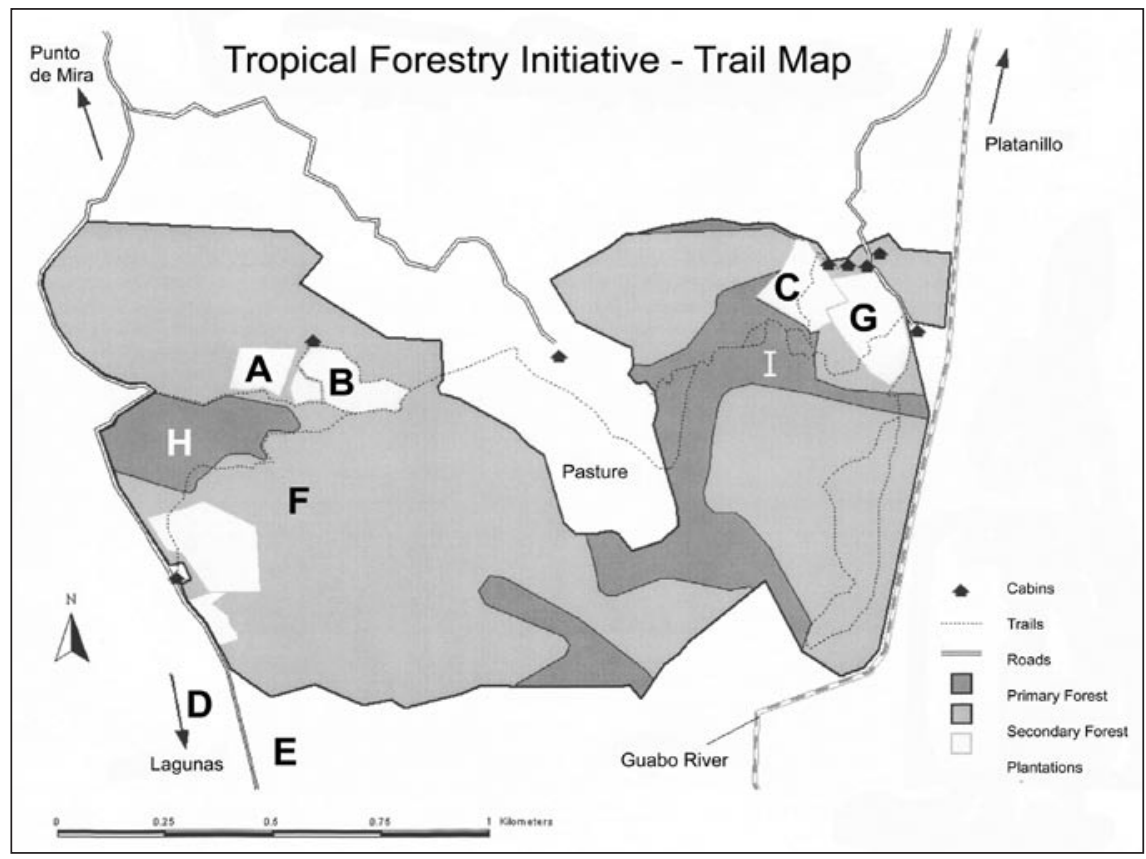

Figure 1. Understory sample plots were located in restoration areas (sites A, B, and C), monoculture plantations ( $D$ and $E$ ), unplanted secondary growth ( $F$ and $G$ ) and primary forest remnants ( $\mathrm{H}$ and I) near Dominical, Costa Rica. A) is in an approximately 8-ha stand of mixed native tree species planted in 1993; B) 4-ha planting started in 1995; C) 2-ha planting started in 1996; D) native pochote (Bombacopsis quinata); E) exotic teak (Tectona grandis).

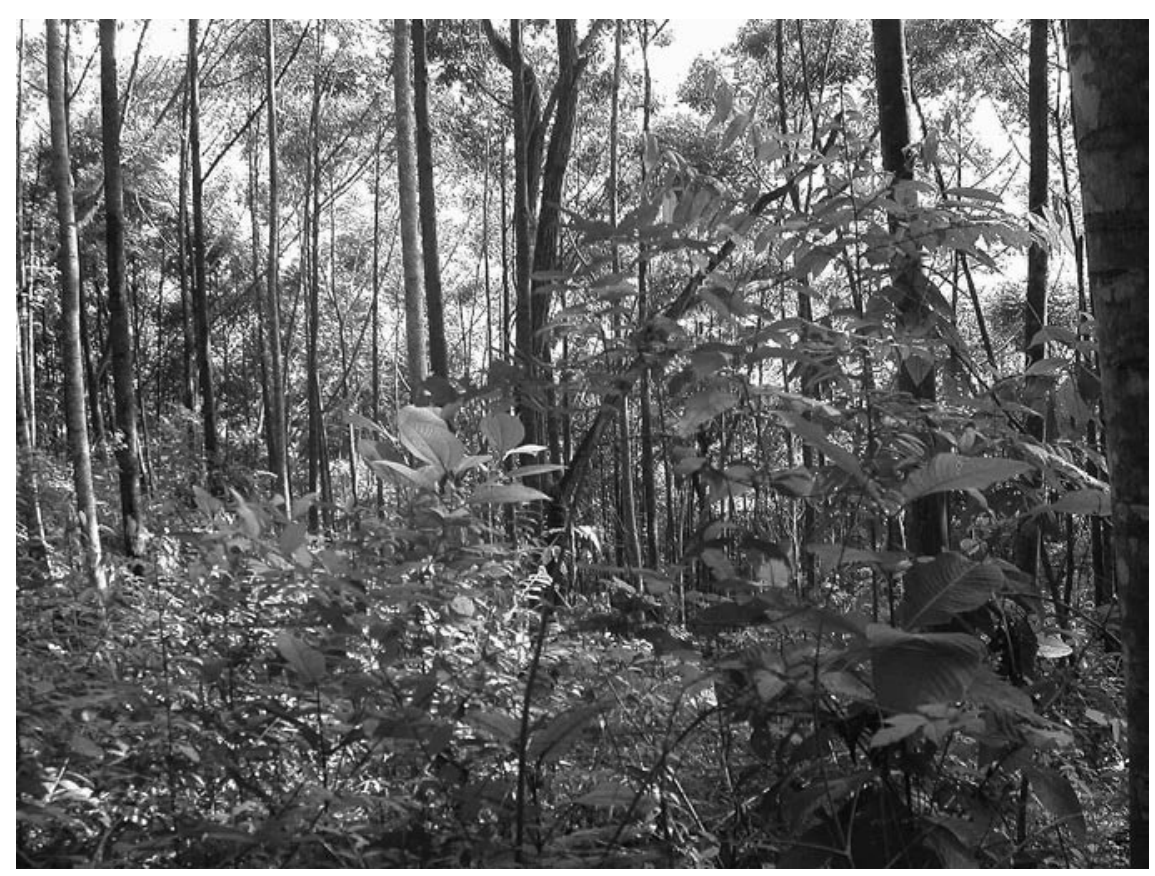

Figure 2. Diverse understory plants have returned to this site of mixed native tree plantings in an abandoned pasture near Dominical, Costa Rica. Planting occurred in 1993 and photo was taken in 2003 by J. Salazar.

Proximity to primary forest remnants is known to be beneficial for facilitating the spread of species (Chazdon 2003), and all plots we surveyed (A through G) were within $250 \mathrm{~m}$ of a primary tropical forest remnant.
(INBio) in San Jose, Costa Rica. Complete sets of the voucher specimens were deposited at the INBio herbarium and at the L.H. Bailey Hortorium herbarium at Cornell University in Ithaca, New York. The listed species will be reported on the Tropical Forestry Initiative web site.

\section{Species Richness in Planted Areas}

The data in Table 2 show species counts ranging from 88 to 113 species in plots from the mixed-tree plantings $(\mathrm{A}-\mathrm{C})$. We did not observe a linear increase in number of species in time between the seven, eight, or ten year-old plantings (plots C, B, and A). The fewer number of species recorded in plot A may be due to the particularly dense canopy formed by mayo colorado (Vochysia ferruginia), which dominates that site. In the two monoculture plantations (D and $\mathrm{E}$ ), understory species were about half as abundant (46-52 species). An inhibitory effect of teak on understory development may have contributed to the low species count for plot E (Healy and Gara 2003). The understory in the unmanaged secondary forest plots was somewhat more diverse than in the plantations (111-134 species).

In the primary forest we counted 92 to 100 species of understory plants. These counts are low in comparison with the 595 understory species reported from Barro Colorado Island and 940 from La Selva, Costa Rica (Gentry 1990). Those counts however are from large-scale surveys, in contrast to our 0.1-ha plots. Our species counts were limited to species on the ground, and excluded epiphytes and lianas, which in La Selva represent almost one-third of the total plant species present (Hammel 1990). Furthermore, the low species counts in our primary forest plots may be reflections of their being small remnants in an agrarian neighborhood that has been settled for at least 50 years. Plots in the monocultures (D and E) showed markedly lower richness, and secondary forest plots 
Table 1. Dominant tree species identified (by local common name) in 0.1-ha plots sampled in 2003 in seven study areas ranging from a 10-year-old site replanted with mixed native tree species (plot A planted in 1993) to secondary rainforest near Dominical, Costa Rica.

\begin{tabular}{|c|c|c|}
\hline Plot & Site & Species \\
\hline \multirow[t]{3}{*}{ A } & 10-y planting & Cedro amargo (Cedrella odorata) \\
\hline & & Gallinazo (Schizolobium parahybum) \\
\hline & & Mayo colorado (Vochysia ferruginea) \\
\hline \multirow[t]{8}{*}{ B } & 8-y planting & Cenicero (Albizia longepedata) \\
\hline & & Cocobolo (Dalbergia retusa) \\
\hline & & Cristobal (Platymiscium pinnatum) \\
\hline & & Espavel (Anacardium excelsum) \\
\hline & & Gallinazo (Schizolobium parahybum) \\
\hline & & Guanacaste (Enterolobium cyclocarpum) \\
\hline & & Guapinol (Hymanaea courbari) \\
\hline & & Mayo colorado (Vochysia ferruginea) \\
\hline \multirow[t]{2}{*}{ C } & 7-y planting & Amarillon (Terminalia amazonia) \\
\hline & & Maria colorado (Calophyllum braziliensis) \\
\hline D & Plantation monoculture & Pochote (Bombacopsis quinata) \\
\hline$E$ & Plantation monoculture & Teak (Tectona grandis) \\
\hline \multirow[t]{7}{*}{$\mathrm{F}$} & Secondary forest & Cecropia (Cecropia peltata) \\
\hline & & Gallinazo (Schizolobium parahybum) \\
\hline & & Guabo (Inga sapindioides) \\
\hline & & Ira (Ocotea ira) \\
\hline & & Lechoso (Brosimum utile) \\
\hline & & Mayo blanco (Vochysia hondurensis) \\
\hline & & Mayo colorado (Vochysia ferruginea) \\
\hline \multirow[t]{6}{*}{ G } & Secondary forest & Achiote (Bixa orellana) \\
\hline & & Bolsa (Ochroma pyramidale) \\
\hline & & Corteza (Tabebuia chrysantha) \\
\hline & & Ira (Ocotea ira) \\
\hline & & Lechoso (Brosimum utile) \\
\hline & & Vainilla (Stryphnodendron microstachyum) \\
\hline
\end{tabular}

(F and G) were somewhat richer than the plantations.

\section{Species Distribution}

There was a predominance of woody species (54-63\%) in the planted plots $(\mathrm{A}, \mathrm{B}$, and $\mathrm{C})$, with herbs and vines being much less abundant (13-20\%) (Table 2). The species were predominantly animal dispersed (62-66\%), with wind-dispersed types being much less frequent (19\% for all plots), and ejection-type seed dispersal being very infrequent. The primary forest plots were even more dominated by woody forms (75-83\%) and by animal dispersed types (77-82\%). Howe and Smallwood (1982) reported slightly lesser dominance of animal dispersal types in primary forests (50-75\%).

The families most abundantly represented in plots $\mathrm{A}, \mathrm{B}$, and $\mathrm{C}$ were Fabaceae (36 species), Melastomataceae (27 species), and Rubiaceae and Euphorbiaceae (each with 17 species). This distribution is reasonably similar to the family distribution in the primary forest plots, where the most abundant families were the Fabaceae (17 species), Melastomataceae (15 species), and Rubiaceae, Euphorbiaceae, and Araceae (each with nine species).

The dominance of leguminous species parallels reports from the Manu Amazon (Foster 1990) and the Barro Colorado forest (Foster and Hubbell 1990) and is consistent with the

Table 2. The numbers and characteristics of understory species sampled in 2003 in seven 0.1-ha plots near Dominical, Costa Rica: three plots in mixed-species plantings (A-C), 2 plots in monoculture plantations (D and E), 2 plots in unplanted areas of secondary forest growth ( $F$ and $G)$, and 2 plots in remnant primary forests $(H$ and $I)$.

\begin{tabular}{|c|c|c|c|c|c|c|c|c|}
\hline \multirow[b]{2}{*}{ Plot } & \multirow[b]{2}{*}{ Site } & \multirow[b]{2}{*}{ Total species } & \multicolumn{3}{|c|}{ Growth form (\%) } & \multicolumn{3}{|c|}{ Dispersal type (\%) } \\
\hline & & & Woody & Herbs & Vines & Animal & Wind & Ejection \\
\hline$A$ & 10-y planting & 88 & 54 & 26 & 20 & 62 & 19 & 1 \\
\hline B & 8-y planting & 113 & 63 & 24 & 13 & 66 & 19 & 3 \\
\hline C & 7-y planting & 109 & 59 & 24 & 17 & 63 & 19 & 2 \\
\hline $\mathrm{D}$ & Pochote (Bombacopsis quinata) & 52 & 61 & 21 & 18 & 59 & 28 & 3 \\
\hline$E$ & Teak (Tectona grandis) & 46 & 57 & 26 & 17 & 63 & 28 & 2 \\
\hline $\mathrm{F}$ & Secondary forest & 134 & 59 & 22 & 19 & 61 & 28 & 1 \\
\hline$G$ & Secondary forest & 111 & 66 & 18 & 19 & 65 & 17 & 0 \\
\hline $\mathrm{H}$ & Primary forest & 92 & 83 & 9 & 8 & 82 & 10 & 3 \\
\hline I & Primary forest & 100 & 75 & 13 & 12 & 77 & 7 & 6 \\
\hline
\end{tabular}


high diversity of legumes typical of lowland neotropical forests (Gentry 1990). At La Selva, Costa Rica, the legume family was less dominant, being only the fifth most abundant family (Hammel 1990). In our plots the family distribution of understory species is highest in the primary forest plots (59 and 55 families) and in the secondary forest plots (54-56 families), intermediate in the 3 native plantations (45-49 families), and lowest in the monocultures (34 families).

One estimate of the progress of this restoration effort is the richness of understory species in common with the primary forest (Figure 3). In the plantations $\mathrm{A}, \mathrm{B}$, and $\mathrm{C}$, and the two secondary forests, $F$ and G, 20-33\% of the species are also found in the primary forest. In the case of the two monocultures, the range of commonality is somewhat lower (22-23\%). The high commonality may be a reflection of the animal-dispersed characteristic, combined with the great abundance of birds and bats to function as dispersal agents. Wind-dispersed or ejection-dispersed species are much less frequent. The "voluntary" occurrence of understory species in the planted plots has been surprisingly rapid considering the time required for crown closure and for the associated demise of pasture plant species (Leopold 2005).

\section{Are We Accomplishing Restoration?}

Estimates of the time required for the maturation of tropical primary forests have ranged from 100 years (Soares-Filho et al. 2001) to 800 years (Kooyman 1996). Our ten-year-old restoration effort clearly has a long way to go. We would expect that the relatively rapid rate during the first decade of restoration would gradually slow over time. After 100 years, plantations of mixed tree species may achieve a forest with species composition similar to the primary forest, although the long-term product will likely have differences from the primary forest.

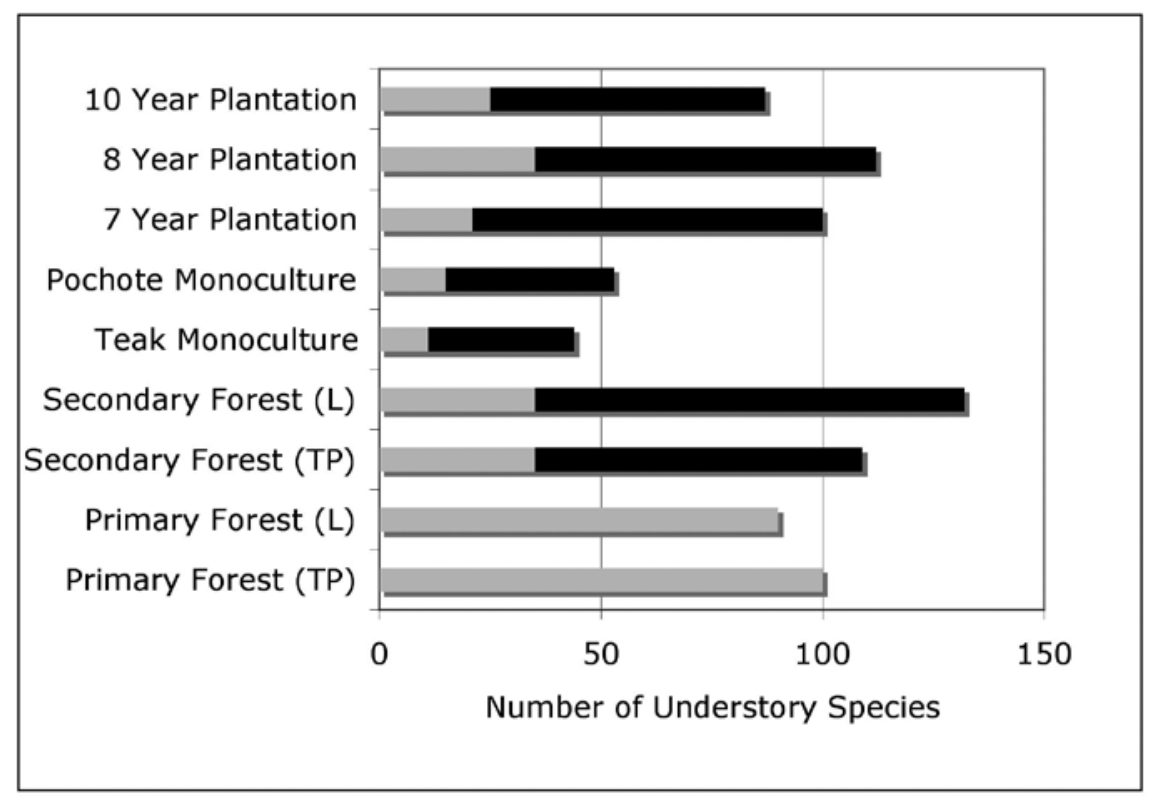

Figure 3. The number of understory species observed in each plot, excluding epiphytes and lianas, near Dominical, Costa Rica. The number of species that are found in common with the primary forest are grey, while black represents the number of observed species not found in the primary forest plots.

Brooks et al. (2006) have raised a question about whether the world's natural ecological systems are irreplaceable; they point out that conservation efforts using monoculture plantations in the tropics have had limited success in bringing about conservation benefits. The concept of real restoration with mixed native species of trees may then be especially important. Our modest effort at restoring local wet tropical forest in Costa Rica may serve as an example of the issues to be expected in efforts to restore this splendid biological resource.

\section{Acknowledgments}

This effort was supported in part by a grant from the USDA Forest Service.

\section{References}

Boley, J.D. 2005. Soil chemistry under a chronosequence of plantations in Costa Rica. M.S. thesis, State University of New York.

Brinson, M.M. and R.D. Rheinhardt. 1996. The role of reference wetlands in functional assessment and mitigation. Ecological Applications 6:69-76.

Brooks, T.M., R.A. Mittermeier, G.A.B. da Fonseca, J. Gerlach, M. Hoffmann, J.F. Lamoreux, C.G. Mittermeier, J.D.
Pilgrim and A.S.L. Rodrigues. 2006. Global biodiversity conservation priorities. Science 313:58-61.

Chazdon, R.L. 2003 Tropical forest recovery: Legacies of human impact and natural disturbances. Perspectives in Plant Ecology, Evolution and Systematics 6:51-71.

Foster, R.B. 1990. Floristic composition of the Rio Manu floodplain forest. Pages 99-111 in A.H. Gentry (ed), Four Neotropical Rainforests. New Haven, CT: Yale University Press.

Foster, R.B. and S.P. Hubbell. 1990. The floristic composition of the Barro Colorado Island forest. Pages 85-98 in A.H. Gentry (ed), Four Neotropical Rainforests. New Haven, CT: Yale University Press.

Gentry, A.W. 1990. Four Neotropical Rainforests. New Haven, CT: Yale University Press.

Haggar, J., K. Wightman and R. Fisher. 1997. The potential of plantations to foster woody regeneration within a deforested landscape in lowland Costa Rica. Forest Ecology and Management 99:55-64.

Hammel, B. 1990. The distribution and diversity among families, genera, and habit types in the La Selva flora. In A.H. Gentry (ed), Four Neotropical Rainforests. New Haven, CT: Yale University Press.

Healy, S.P. and R.I. Gara. 2003. The effect of a teak (Tectona grandis) plantation on 
the establishment of native species in an abandoned pasture in Costa Rica. Forest Ecology Management 176:497-507.

Howe, H.F. and J. Smallwood, 1982. Ecology of seed dispersal. Annual Review of Ecology and Systematics 13:201-228.

Kooyman, R.M. 1996. Growing Rainforest: Restoration and Regeneration. Brisbane: Greening Australia-Queensland.

Lamb, D., P.D. Erskine and J.A. Parrota. 2005. Restoration of degraded tropical forest landscapes. Science 310:1628-1632.

Leopold, A.C. 2005. Toward restoration of a wet tropical forest in Costa Rica: A ten-year report. Ecological Restoration. 23:230-234.
Leopold, A.C., R. Andrus, A. Finkeldey and D. Knowles. 2001. Attempting restoration of wet tropical forests in Costa Rica. Forest Ecology Management 142:243-249.

Panayatou, T. and P.S. Ashton.1992. Not By Timber Alone. Washington, DC: Island Press.

Peñuela, M.C. 2001. Assessing the restoration of ecological function of abandoned pastures on tropical wet forest lands in Costa Rica. M.S. thesis, State University of New York.

Soares-Filho, B.S., R.M. Assunção and A.E. Pantuzzo. 2001. Modeling the spatial transition probabilities of landscape dynamics in an Amazonian colonization frontier. BioScience 51:1059-1067.
A. Carl Leopold, Boyce Thompson Institute for Plant Research and L.H. Bailey Hortorium, Cornell University, Ithaca NY 14853, 607/254-1327, Fax: 607/254-1242,acl9@cornell.edu

Jackeline Salazar, Calle Arenas, Edif Cedro V, Apta 101, Miramar, Res Palmas del Mar, Santo Domingo, Dominican Republic, jackeline.salazar@hotmail.com 